\title{
Bronze Age meat industry: ancient mitochondrial DNA analyses of pig bones from the prehistoric salt mines of Hallstatt (Austria)
}

\author{
Sabine E. Hammer ${ }^{1 *}$, Barbara Tautscher ${ }^{2}$, Erich Pucher ${ }^{3}$, Kerstin Kowarik ${ }^{4}$, Hans Reschreiter ${ }^{4}$, Anton Kern ${ }^{4}$ \\ and Elisabeth Haring ${ }^{2,5}$
}

\begin{abstract}
Objective: In the Bronze Age Hallstatt metropolis ('Salzkammergut' region, Upper Austria), salt richness enabled the preservation of pork meat to sustain people's livelihood suggesting an organized meat production industry on a yearly basis of hundreds of pigs. To pattern the geographic and temporal framework of the early management of pig populations in the surrounding areas of Hallstatt, we want to gain insights into the phylogeographic network based on DNA sequence variation among modern pigs, wild boars and prehistoric (likely) domestic pigs.

Results: In this pilot study, we successfully adapted ancient DNA extraction and sequencing approaches for the analysis of mitochondrial DNA sequence variation in ten prehistoric porcine teeth specimens. Minimum-spanning network analyses revealed unique mitochondrial control region DNA haplotypes ranging within the variation of modern domestic pig and wild boar lineages and even shared haplotypes between prehistoric and modern domestic pigs and wild boars were observed.
\end{abstract}

Keywords: Hallstatt, Bronze Age, Sus scrofa, Ancient DNA, Mitochondrial DNA, Phylogeographic network

\section{Introduction}

The UNESCO World Heritage Hallstatt-Dachstein/Salzkammergut, located in the eastern Austrian alps, represents one of the most important prehistoric production centres in Europe. Underground salt mining at depths of up to $170 \mathrm{~m}$ is attested as far back as 1500 years BC [1, $2]$. Due to the high salt concentrations inside the prehistoric mining galleries, the remains of the extraction activity have been perfectly preserved $[3,4]$. The size of the mining areas and the amount of mining waste evidence production on a large scale as well as a highly structured and technologically well-developed organization $[1,2]$. Set in an alpine environment, with the production and settlement areas located in a narrow valley at an elevation

\footnotetext{
*Correspondence: sabine.hammer@phylo-dat.net

${ }^{1}$ Institute of Immunology, Department of Pathobiology, University of Veterinary Medicine Vienna, Veterinaerplatz 1, 1210 Vienna, Austria Full list of author information is available at the end of the article
}

of $1000 \mathrm{~m}$ above sea level (MASL), the prehistoric mining community was nonetheless able to meet the exacting demands of the large scale production activity. In Bronze Age, economic activity encompassed not only salt extraction, but also the production of cured meat, mainly from pig, on a very large scale. A special butchering technique, documented through thousands of pig bones, as well as facilities for curing the meat, 8 log basins with the capacity to hold up to 200 butchered pigs, attest to the developed organization and scale of this meat production industry. Currently archaeological data indicates that the meat of several hundred pigs was annually processed and cured in the Hallstatt High Valley [5-7]. The archaeozoological analysis of the bone inventory evidences a well organised system based on the breeding of animals for the "meat industry" and the transport of meat from the animal breeders to the Hallstatt High Valley. Morphological differences point to different areas of the pigs' origin, 
to the North along the Traun river and to the Southeast towards the Styrian Salzkammergut [8].

The large scope of the project should delineate the geographic and temporal framework of the early management of pig populations in the surrounding areas of Hallstatt and allow to estimate the spatial extent of the catchment areas. These attempts should help to answer the questions which husbandries delivered pigs to Hallstatt and whether or not a natural pig breeding monopoly existed during the Hallstatt period. Ancient DNA elucidates phylogenetic relationships of pigs allowing insights into prehistoric farming practices as well as adaptation and domestication of pigs [9-13]. The high abundance of porcine teeth remnants at the Hallstatt High Valley initiated this pilot study to assess the suitability of this material for molecular genetic analyses. The study gained first insights into genetic variation in a neutral DNA marker sequence, the mitochondrial $(\mathrm{mt})$ control region $(\mathrm{CR})$ and thus will pave the way for deeper molecular analyses by nuclear marker assessment.

\section{Main text \\ Methods \\ Animals and sample collection}

The studied material comprises 10 mandibular cuspids (fangs), mainly from castrated males, excavated in 1939 and 1993/94 in the Hallstatt High Valley ('Salzkammergut' region, Upper Austria) (Table 1). The town of Hallstatt is situated at $47.56^{\circ}$ North latitude, $13.65^{\circ}$ East longitude and 514 MASL. The analysed specimens derived from an thick layer of animal bone assemblage being radiocarbon dated to the 13th/12th century BC, the Late Bronze Age $[1,2]$. These animal bones are part of the Archaeozoological Collection at the Natural History Museum Vienna (NHMW), Austria. Detailed information on prehistoric pig specimens as well as modern Sus scrofa and Suinae taxa of the present study is given in Table 1.

\section{DNA extraction}

DNA extractions were performed in a clean room by obeying all standard routines for working with aDNA $[14,15]$ (For details see Additional file 1). Cleaning and decontamination of grinding bowls and balls was performed with DNA-Away ${ }^{1}$ after an ultrasonic bath followed by subsequent UV radiation. All post-PCR work was carried out in a separate laboratory. Extraction controls (buffers without sample) were performed to screen for contaminated extraction reagents. For each specimen, at least two independent DNA extractions were

\footnotetext{
${ }^{1}$ Molecular BioProducts (San Diego, CA).
}

performed. The detailed protocol for DNA extraction is given in Additional file 1. Briefly, prior to the DNA extraction, the surface of each tooth was treated with $3 \%$ sodium hypochlorite and rinsed in nuclease free water ${ }^{2}$ for decontamination [16]. The dried teeth were crushed into small pieces and pulverized with a Retsch MM400 grinding mill. ${ }^{3}$ Next, $1 \mathrm{~g}$ tooth powder was decalcified three times by adding $4.5 \mathrm{ml}$ Decalcifier soft ${ }^{4}$ (containing $25 \%$ EDTA) and rotating overnight incubation at $4{ }^{\circ} \mathrm{C}$. Following centrifugation (Eppendorf Centrifuge $5430^{5}$ ), the supernatant was discarded and replaced by $4.5 \mathrm{ml}$ fresh decalcifying solution. After decalcification, the powder was washed three times by adding $4.5 \mathrm{ml}$ nuclease free water to remove all remains of EDTA. The rinsed powder was subjected to DNA extraction with the Genial All Tissue Kit ${ }^{6}$ according to the manufacturer's instructions for DNA extraction from bone to teeth. Finally, the DNA was dissolved in $30 \mu \mathrm{l}$ nuclease free water (see footnote 2) and after concentration measurement (BioPhotometer D30, $\mu$ Cuvette G1.0) (see footnote $5)$, the DNA solutions were immediately aliquoted (5-10 $\mu \mathrm{l})$ and stored at $4{ }^{\circ} \mathrm{C}$ (short term) or at $-20^{\circ} \mathrm{C}$ for long term.

\section{PCR amplification of the mitochondrial control region}

A 721-basepair-long section of the mitochondrial control region was amplified using three PCR primer pairs that produce three overlapping amplicons, ranging from 343 to 401 base pairs (bp) in length (Additional files 2, 3 and 4). PCR was performed with Amplitaq Gold ${ }^{\circledR} 360$ DNAPolymerase $^{7}$ and PCR reactions were run on a Mastercycler Nexus (See footnote 5) by applying conventional thermal cycling conditions and touch-down protocols (Additional file 1). Failed PCR reactions were repeated with varying amounts of template DNA. Control PCR reactions were performed to screen for contaminated reagents: extraction control (buffers without sample) and non-template control with nuclease-free water instead of template. Finally, PCR products were purified with the QIAquick PCR Purification Kit (see footnote 2) and sequenced (both directions using the PCR primers) at Microsynth $\mathrm{AG}^{8}$ and LGC Genomics. ${ }^{9}$

\footnotetext{
${ }^{2}$ Qiagen (Hilden, Germany).

${ }^{3}$ Retsch GmbH (Haan, Germany).

${ }^{4}$ Carl Roth (Karlsruhe, Germany).

${ }^{5}$ Eppendorf AG (Hamburg, Germany).

${ }^{6}$ GEN-IAL (Troisdorf, Germany).

7 Thermo Fisher Scientific (Waltham, MA).

${ }^{8}$ Microsynth AG (Balgach, Switzerland).

${ }^{9}$ LGC Genomics (Berlin, Germany).
} 
Table 1 List of mitochondrial DNA sequences of prehistoric and modern domestic pigs, wild boars and Suinae obtained in the present study or downloaded from GenBank

\begin{tabular}{|c|c|c|c|c|c|c|}
\hline Accession no & Tree/network label & Location & Species & Status & Breed & Source \\
\hline MG926393 & H45-1 (AT) & Austria & $\underline{\text { Sus scrofa f. domestica }}$ & Prehistoric domestic & - & This study \\
\hline MG926394 & HoN-4 (AT) & Austria & $\underline{\text { Sus scrofa f. domestica }}$ & Prehistoric domestic & - & $\underline{\text { This study }}$ \\
\hline MG926395 & $\underline{H 405-5(A T)}$ & Austria & $\underline{\text { Sus scrofa f. domestica }}$ & Prehistoric domestic & - & This study \\
\hline MG926396 & $\underline{H 124-6(A T)}$ & $\underline{\text { Austria }}$ & $\underline{\text { Sus scrofa f. domestica }}$ & Prehistoric domestic & - & This study \\
\hline MG926397 & $\underline{H} 288-7(A T)$ & $\underline{\text { Austria }}$ & $\underline{\text { Sus scrofa f. domestica }}$ & Prehistoric domestic & - & This study \\
\hline MG926398 & $\underline{H 51-1(A T)}$ & $\underline{\text { Austria }}$ & $\underline{\text { Sus scrofa f. domestica }}$ & Prehistoric domestic & - & This study \\
\hline MG926393 & $\underline{H 117-21(A T)}$ & $\underline{\text { Austria }}$ & $\underline{\text { Sus scrofa f. domestica }}$ & Prehistoric domestic & - & This study \\
\hline MG926393 & $\underline{H 136-3(A T)}$ & $\underline{\text { Austria }}$ & $\underline{\text { Sus scrofa f. domestica }}$ & Prehistoric domestic & - & This study \\
\hline DQ379225 & Saddleback (DE) & Germany & Sus scrofa f. domestica & Domestic & Angeln Saddleback & [29] \\
\hline AY884775 & Landrace-01 (FI) & Finland & Sus scrofa f. domestica & Domestic & Landrace & [9] \\
\hline AY884748 & Landrace-02 (NO) & Norway & Sus scrofa f. domestica & Domestic & Landrace & [9] \\
\hline AY884746 & Duroc (GB) & United Kingdom & Sus scrofa f. domestica & Domestic & Duroc & [9] \\
\hline AY884779 & Creole (FR) & France & Sus scrofa f. domestica & Domestic & Creole & [9] \\
\hline DQ152846 & Large White (EU) & Europe & Sus scrofa f. domestica & Domestic & Large White & {$[29]$} \\
\hline AY884763 & Large White (FR) & France & Sus scrofa f. domestica & Domestic & Large White & [9] \\
\hline AY884785 & Large White (DE) & Germany & Sus scrofa f. domestica & Domestic & Large White & [9] \\
\hline AY884751 & Linderodssvin (SE) & Sweden & Sus scrofa f. domestica & Domestic & Linderodssvin & [9] \\
\hline AY884769 & Piétrain (DE) & Germany & Sus scrofa f. domestica & Domestic & Piétrain & [9] \\
\hline AY884764 & Mangalica (HU) & Hungaria & Sus scrofa f. domestica & Domestic & Mangalica & [9] \\
\hline DQ152879 & Bamei (CN) & China & Sus scrofa f. domestica & Domestic & Bamei & {$[29]$} \\
\hline DQ152886 & Huzhu (CN) & China & Sus scrofa f. domestica & Domestic & Huzhu & [29] \\
\hline DQ379162 & Meishan (CN) & China & Sus scrofa f. domestica & Domestic & Meishan & {$[29]$} \\
\hline DQ152868 & Zang (CN) & China & Sus scrofa f. domestica & Domestic & Zang & [29] \\
\hline HM747197 & Wild boar (AT) & Austria & Sus scrofa & Wild & - & [29] \\
\hline AY884664 & Wild boar (DE) & Germany & Sus scrofa & Wild & - & [9] \\
\hline DQ379236 & Wild boar (BE) & Belgium & Sus scrofa & Wild & - & {$[29]$} \\
\hline DQ379253 & Wild boar-1 (FR) & France & Sus scrofa & Wild & - & {$[29]$} \\
\hline DQ379244 & Wild boar-2 (FR) & France & Sus scrofa & Wild & - & {$[29]$} \\
\hline FJ236998 & Wild boar (ES) & Spain & Sus scrofa & Wild & - & $\begin{array}{l}\text { Fernandez Al } \\
\quad(26-S E P-2008)\end{array}$ \\
\hline AY884672 & Wild boar (NO) & Norway & Sus scrofa & Wild & - & [9] \\
\hline AY884670 & Wild boar (MK) & Mecedonia & Sus scrofa & Wild & - & [9] \\
\hline AY884726 & Wild boar (AM) & Armenia & Sus scrofa & Wild & - & [9] \\
\hline DQ872938 & Wild boar-1 (IR) & Iran & Sus scrofa & Wild & - & [9] \\
\hline DQ872956 & Wild boar-2 (IR) & Iran & Sus scrofa & Wild & - & [9] \\
\hline AY884612 & Wild boar (IN) & India & Sus scrofa & Wild & - & [9] \\
\hline AY884661 & Wild boar (ID) & Indonesia & Sus scrofa & Wild & - & [9] \\
\hline DQ379262 & Wild boar-1 (CN) & China & Sus scrofa & Wild & - & {$[29]$} \\
\hline DQ379266 & Wild boar-2 (CN) & China & Sus scrofa & Wild & - & {$[29]$} \\
\hline AY884702 & S. scrofa papuensis & Papua New Guinea & Sus scrofa papuensis & Wild & - & [9] \\
\hline AY884708 & S. scrofa taiwanensis & Taiwan & Sus scrofa taiwanensis & Wild & - & [9] \\
\hline AY884705 & S. scrofa andamensis & Andaman Islands (India) & Sus scrofa andamensis & Wild & - & [9] \\
\hline KF952600 & Sus cebifrons & Philippines & Sus cebifrons & Wild & - & $\begin{array}{l}\text { Si T (10-DEC- } \\
\text { 2013) }\end{array}$ \\
\hline KP789021 & Sus barbatus & Southeast Asia & Sus barbatus & Wild & - & $\begin{array}{l}\text { Zhang S (13- } \\
\text { FEB-2015) }\end{array}$ \\
\hline KF926379 & Sus verrucosus & Indonesian & Sus verrucosus & Wild & - & $\begin{array}{l}\text { Fan J (03-DEC- } \\
\text { 2013) }\end{array}$ \\
\hline
\end{tabular}




\section{DNA sequence analysis and phylogenetic reconstruction}

BioEdit Sequence Alignment Editor (v7.2.5) was used for nucleotide sequence alignment and sequence editing [17]. The final dataset including previously published sequences (GenBank) had a length of 637 sites and comprised 42 sequences. Trees were calculated by the Neighbor-Joining (NJ) method [18], by Maximum-Likelihood $(\mathrm{ML})$ as well as Bayesian inference (BI) using the software MEGA7 [19] for NJ and ML trees and MrBayes v3.2 [20] for BI trees. For the NJ analysis, the evolutionary distances were computed using the $p$-distance method [21] and are in the units of the number of base differences per site. The ML method was based on the Tamura 3-parameter model [22] with a discrete Gamma distribution to model evolutionary rate differences among sites (two categories: $G=0.58, I=0.75$ ). Parameters for $\mathrm{BI}$ analysis were as follows: lset $n s t=2$ rates $=$ gamma [20]. FigTree v1.4.3 [23] was used to annotate the consensus tree produced by MrBayes. The unrooted phylogenetic network was constructed with PopART $[24,25]$ by applying the minimum spanning option.

\section{Results and discussion}

Out of the ten samples analysed, seven allowed to determine the complete CR marker sequence (637 bp), whereas two were unsuccessful and one allowed to amplify fragment B (342 bp), only. Sequences obtained in the present study are deposited in GenBank (Accession no's MG926393-MG926400, Table 1).

As can be seen in Additional file 5, PCR success is not strictly correlated with DNA concentrations e.g., one of the unsuccessful samples, H188-7 proved to have the highest DNA concentrations, while the sample with the lowest concentration H117-21 allowed to amplify all fragments. Unfortunately, the overall amount of DNA that could be extracted from each tooth was limited and thus only a few PCR trials were possible until the DNA was completely used up. Since DNA concentration seems to be not a reliable predictor of fragmentation it appears reasonable to further reduce the amplicon size. This will of course increase the effort necessary to obtain complete sequences, but, on the other hand, will allow to determine the sequence from a higher number of samples. Three samples (H451, H117-21, HoN-4) delivered sequences without any ambiguities, while in samples H405-5, H288-7, H51-1, and H124-6 several ambiguous sites were found, which could be interpreted as derived from post-mortem modifications. Almost all of them could be determined by repetition of PCR and subsequent sequencing as well as with the information from overlapping regions. Only in sample H124-6 two C/T ambiguities could not be resolved and are coded as $\mathrm{Y}$ in the alignment.
The final alignment (637 bp) comprising 42 sequences of prehistoric and modern domestic pigs, wild boars and Suinae (Table 1) had 567 conserved and 35 parsimony informative sites. The $p$-distances among prehistoric domestic pigs ranged from 0.2 to $3.2 \%$ (average $1.1 \%$ ), while distances within the in-group were up to 3.9\% (average 1.6\%) and between S. scrofa and the outgroup taxa distances ranged from 2.4 to $5.7 \%$ (average 3.7\%) (Additional file 6). A minimum spanning network based on this alignment is roughly divided into two groups (Fig. 1). Interestingly, the "Asian" group includes sequences of Asian as well as European origin, as well as the outgroup taxa. In contrast, the "European" group exclusively consists of sequences derived from European breeds as well as prehistoric pigs from Hallstatt. One sequence from Hallstatt (HoN4) has an intermediate position between the two haplogroups. The inclusion of the outgroup sequences into the network illustrates that distances within S. scrofa are almost in the same range as between $S$. scrofa and the outgroup (see also Additional files 6,7). A rooted NJ tree is given in Additional file 8 to alternatively illustrate the distances between sequences and shows the same overall topology as the ML and BI trees (support values of all analyses are included in the $\mathrm{NJ}$ tree in Additional files $8,9)$. As the separation into two haplogroups is not well supported in this NJ tree, future analyses of additional markers should help to support this geographic pattern. Concerning the distribution of prehistoric samples in the network, there are two shared haplotypes harboured by prehistoric as well as modern pigs: H288-7 was identical with a Wild boar specimen from Norway to H45-1 and H405-5 shared the same haplotype with a British Duroc and the French Wild boar-1.

\section{Conclusions}

There are three major outcomes: (1) The results indicate that the teeth are suitable material to obtain genetic information from prehistoric Sus domestica (S. scrofa f. domestica) from Hallstatt. Next steps are to test nuclear markers (e.g., nuclear DNA sequences of mitochondrial origin (numts) [26]; Y chromosome, MCR1 [27]; SLADRB1 [28]) with the tooth material as well as bones to assess the potential success of genomic analyses. (2) The variety found in the mitochondrial marker sequence of prehistoric pigs is almost as high as found among present day S. scrofa (Wild boar and breeds). Although the data presented here can be considered only as first hints, they are in favour for the assumption that the Hallstatt pigs were derived from large herds and/or various husbandries. However, the placement of prehistoric pigs in the haplotype network and the phylogenetic tree do not allow to draw conclusions about their geographical origin 


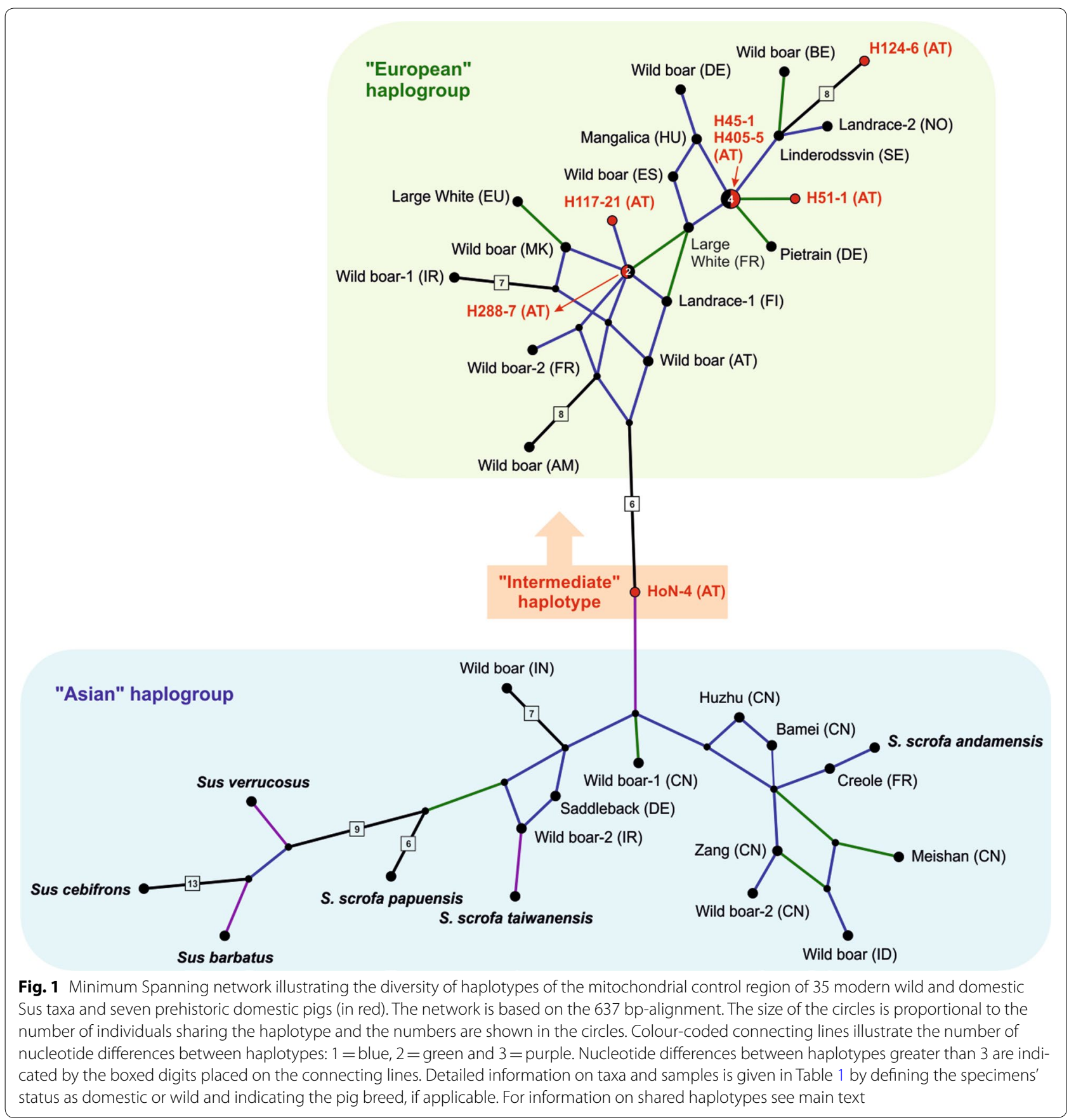

and status (wild vs. domesticated). The results are in accordance with earlier findings implying repeated gene flow between wild boar and domestic breeds $[9,29,30]$. (3) With the exception of the intermediate haplotype, all prehistoric pigs from Hallstatt resemble haplotypes of the "European" group. Shared haplotypes between prehistoric and modern S. scrofa indicate that Hallstatt pigs did not represent an independent lineage, but seem to range within the variation of extant $S$. scrofa.

\section{Limitations}

Limitations of this study were mainly due to the low number of prehistoric pigs that have been analysed and the fact that DNA sequence analyses in this pilot study are based on a single mitochondrial marker system. Moreover, the suitability of other bony material for obtaining genetic information from prehistoric pig specimens has to be proven in subsequent experiments. Future nuclear marker assessments will assist in drawing 
a clearer picture of prehistoric Hallstatt's meat production and surrounding husbandries. However, any signal could be blurred by a substantial amount of gene flow between geographic regions as well as between wild boars and domesticated pigs.

\section{Additional files}

Additional file 1. Ancient DNA extraction and Mitochondrial control region PCR. Detailed protocols for Ancient DNA extraction and PCR of mitochondrial control region.

Additional file 2. Map of the porcine mitochondrial DNA. Localisation of the 721 bp long control region (CR) fragment in the reference mitochondrial genome.

Additional file 3. PCR strategy for the 721-bp-long section of the mitochondrial Control Region (CR). The CR sequences were inferred using three PCR primer pairs that allow amplification of overlapping amplicons, ranging from $343 \mathrm{bp}$ to $401 \mathrm{bp}$ in length.

Additional file 4. PCR strategy for the 721-bp-long section of the mitochondrial Control Region (CR). Primers used to amplify three sections (A, B, C) of the mitochondrial control region.

Additional file 5. Detailed sequencing outcome for the 10 prehistoric porcine teeth specimens. For each specimen, DNA concentration and the number of obtained sequence reads for fragments $A, B$ and $C$, are given.

Additional file 6. Phylogenetic Reconstruction I-estimates of evolutionary divergence between sequences. Distance matrix shows the number of base differences per site ( $p$ distances; Nei and Kumar 2000) between 42 DNA sequences (length of alignment 637 bp).

Additional file 7. Phylogenetic Reconstruction II-Maximum Likelihood fits of 24 different nucleotide substitution models. Summarizing table for the models with the lowest BIC scores (Bayesian Information Criterion) that are considered to describe the substitution pattern the best.

Additional file 8. Phylogenetic Reconstruction III-Neighbor-Joining Tree. Neighbor-Joining (NJ) tree illustrating distances and phylogenetic relationships among porcine haplotypes of the $637 \mathrm{bp}$-alignment of the mitochondrial control region of 42 domestic, wild and prehistoric domestic pigs.

Additional file 9. Supplementary references. Publications being cited in Additional files 1-9.

\section{Abbreviations}

UNESCO: United Nations Educational, Scientific and Cultural Organization; BC: before Christ; MASL: meters above sea level; mt: mitochondrial; CR: control region; NHMW: Natural History Museum Vienna; EDTA: ethylene diamine tetraacetic acid; PCR: polymerase chain reaction; bp: base pairs; NJ: NeighborJoining; ML: Maximum-Likelihood; BI: Bayesian inference; MEGA: molecular evolutionary genetics analysis; numts: nuclear DNA sequences of mitochondrial origin; MCR1: melanocortin receptor 1.

\section{Authors' contributions}

SEH, EH and HR conceived and designed the study. SEH and EH designed and performed experiments, supervised research and wrote the manuscript with input from all authors. BT designed and performed experiments. SEH and EH interpreted the results and drafted the manuscript. BT, KK and HR helped prepare the manuscript. KK and AK initiated the study and provided specimenspecific information. EP provided access to the collection and specimen-specific information. All authors read and approved the final manuscript.

\section{Author details}

${ }^{1}$ Institute of Immunology, Department of Pathobiology, University of Veterinary Medicine Vienna, Veterinaerplatz 1, 1210 Vienna, Austria. ${ }^{2}$ Central Research Laboratories, Museum of Natural History Vienna, Burgring 7, 1010 Vienna, Austria. ${ }^{3}$ 1st Zoological Department, Archaeozoological
Collection, Museum of Natural History Vienna, Burgring 7, 1010 Vienna Austria. ${ }^{4}$ Prehistoric Department, Museum of Natural History Vienna, Burgring 7, 1010 Vienna, Austria. ${ }^{5}$ Department of Integrative Zoology, University of Vienna, Althanstrasse 14, 1090 Vienna, Austria.

\section{Acknowledgements}

The authors would like to thank Wilhelm Pinsker for critical reading of the manuscript.

\section{Competing interests}

The authors declare that they have no competing interests.

\section{Availability of data and materials}

The datasets used and/or analysed during the current study are available from the corresponding author on reasonable request.

\section{Consent for publication}

Not applicable.

Ethics approval and consent to participate

Not applicable.

Funding

Not applicable.

\section{Publisher's Note}

Springer Nature remains neutral with regard to jurisdictional claims in published maps and institutional affiliations.

Received: 14 February 2018 Accepted: 30 March 2018

Published online: 13 April 2018

\section{References}

1. Kern A, Kowarik K, Rausch AW, Reschreiter H. Kingdom of Salt. 7000 years of Hallstatt. 3rd ed. Vienna: Department of Prehistory (VPA), Natural History Museum; 2009

2. Reschreiter H. In: Grömer K, Kern A, Reschreiter H, Rösl-Mautendorfer H, editors. The prehistoric salt-mines of Hallstatt/Das Salzbergwerk Hallstatt. Budapest: Textiles from Hallstatt; 2013. p. 13-32.

3. Reschreiter H, Miller Dv, Gengler C, Kalabis S, Zangerl N, Fürhacker R, et al. Aus dem Salz ins Depot - Organische Funde aus den prähistorischen Salzbergwerken von Hallstatt. Wien: Österreichische Zeitschrift für Kunstund Denkmalpflege; 2014. p. 354-67.

4. Piñar G, Dalnodar D, Voitl C, Reschreiter H, Sterflinger K. Biodeterioration risk threatens the 3100 year old staircase of Hallstatt (Austria): possible involvement of halophilic microorganisms. PLoS ONE. 2016;11:e148279.

5. Pucher E. Hallstatt and Dürrnberg - two salt-mining sites, two different meat supply strategies. In: Anreiter P et al. (ed.) Mining in European history and its impact on environment and human societies. 2010. Proceedings for the 1st mining in european history-conference of the SFB-HIMAT, 12-15. November 2009, Innsbruck. pp. 193-197, Innsbruck: Innsbruck University Press.

6. Pucher E, Barth FE, Seemann R, Brandstätter F. Bronzezeitliche Fleischverarbeitung im Salzbergtal bei Hallstatt. In: Pucher E, Barth FE, Seemann R, Brandstätter F, editors. Bronzezeitliche Fleischverarbeitung im Salzbergtal bei Hallstatt. 80th ed. Vienna: Mitteilungen der Prähistorischen Kommission, Österreichische Akademie der Wissenschaften, Philosophischhistorische Klasse; 2013. p. 11-134.

7. Barth FE. Die Blockwandbauten des Salzbergtales bei Hallstatt und ihre Verwendung. In: Pucher E, Barth FE, Seemann R, Brandstätter F, editors. Bronzezeitliche Fleischverarbeitung im Salzbergtal bei Hallstatt. 80th ed. Vienna: Mitteilungen der Prähistorischen Kommission, Österreichische Akademie der Wissenschaften, Philosophisch-historische Klasse; 2013. p. 93-134.

8. Pucher E. Neue Aspekte zur Versorgungslogistik Hallstatts: Tierknochenfundkomplexe aus Pichl, Steiermark. Fundberichte aus Österreich. 2014;52:65-93 
9. Larson G, Dobney K, Albarella U, Fang M, Matisoo-Smith E, Robins J, Lowden S, Finlayson H, Brand T, Willerslev E, Rowley-Conwy P, Andersson L, Cooper A. Worldwide phylogeography of wild boar reveals multiple centers of pig domestication. Science. 2005;307:1618-21.

10. Larson G, Liuc R, Zhaoc X, Yuan J, Fuller D, Barton L, Dobney K, Fan Q, Gu Z, Liu X-H, Luo Y, Lv P, Andersson L, Li N. Patterns of East Asian pig domestication, migration, and turnover revealed by modern and ancient DNA. Proc Natl Acad Sci USA. 2010;107:7687.

11. Hammer SE, Däubl B, Pucher E, Barth F-E, Kern A, Haring E, Reschreiter H. Ancient mitochondrial DNA analyses of Bronze Age pigs from Hallstattresults from a pilot study. Mammal Biol. 2016;81(Suppl. 1):7.

12. Zhang J, Jiao T, Zhao S. Genetic diversity in the mitochondrial DNA D-loop region of global swine (Sus scrofa) populations. Biochem Biophys Res Commun. 2016;473:814-20.

13. Caliebe A, Nebel A, Makarewicz C, Krawczak M, Krause-Kyora B. Insights into early pig domestication provided by ancient DNA analysis. Sci Rep. 2017;7:44550.

14. Cooper A, Poinar HN. Ancient DNA: do it right or not at all. Science. 2000;289:1139.

15. Haring E, Voyta LL, Däubl B, Tiunov MP. Comparison of genetic and morphological characters in fossil teeth of grey voles from the Russian Far East (Rodentia: Cricetidae: Alexandromys). Mammal Biol. 2015:80:496-504.

16. Watt KA (2005). Decontamination techniques in ancient DNA analysis. Master thesis, Simon Fraser University, Burnaby, BC, Canada.

17. Hall TA. BioEdit: a user-friendly biological sequence alignment editor and analysis program for Windows 95/98/NT. Nucl Acids Symp Ser. 1999:41:95-8

18. Saitou N, Nei M. The neighbor-joining method: a new method for reconstructing phylogenetic trees. Mol Biol Evol. 1987:4:406-25.

19. Kumar S, Stecher G, Tamura K. MEGA7: molecular evolutionary genetics analysis version 7.0 for bigger datasets. Mol Biol Evol. 2016;33:1870-4.
20. Ronquist F, Teslenko M, van der Mark P, Ayres DL, Darling A, Höhna S, Larget B, Liu L, Suchard MA, Huelsenbeck JP. MrBayes 3.2: efficient Bayesan phylogenetic inference and model choice across a large model space. Syst Biol. 2012;61:539-42.

21. Nei M, Kumar S. Molecular evolution and phylogenetics. New York: Oxford University Press; 2000.

22. Tamura K. Estimation of the number of nucleotide substitutions when there are strong transition-transversion and $\mathrm{G}+\mathrm{C}$-content biases. Mol Biol Evol. 1992;9:678-87.

23. Rambaut A (2006-2016) FigTree-a tree figure drawing tool, v1.4.3. http://tree.bio.ed.ac.uk/software/figtree/. Accessed 10 August 2017.

24. Bandelt H, Forster P, Röhl A. Median-joining networks for inferring intraspecific phylogenies. Mol Biol Evol. 1999;16:37-48.

25. Leigh JW, Bryant D. PopART: full-feature software for haplotype network construction. Methods Ecol Evol. 2015;6:1110-6.

26. Schiavo G, Hoffmann Ol, Ribani A, Utzeri VJ, Ghionda MC, Bertolini F, Geraci C, Bovo S, Fontanesi L. A genomic landscape of mitochondrial DNA insertions in the pig nuclear genome provides evolutionary signatures of interspecies admixture. DNA Res. 2017;24:487-98.

27. Adeola $\mathrm{AC}$, et al. Analysis of the genetic variation in mitochondrial DNA Y-chromosome sequences, and MC1R sheds light on the ancestry of Nigerian indigenous pigs. Genet Sel Evol. 2017:49:52.

28. Moutou KA, Koutsogiannouli EA, Stamatis C, Billinis C, Kalbe C, Scandura $\mathrm{M}$, Mamuris Z. Domestication does not narrow MHC diversity in Sus scrofa. Immunogenetics. 2013;65:195-209.

29. Fang M, Andersson L. Mitochondrial diversity in European and Chinese pigs is consistent with population expansions that occurred prior to domestication. Proc Biol Sci USA. 2006;273:1803-10.

30. Alves PC, Pinheiro I, Godinho R, Vicente J, Gortazar C, Scandura M. Genetic diversity of wild boar populations and domestic pig breeds (Sus scrofa) in South-western Europe. Biol J Linn Soc Lond. 2010;101:797-822.
Ready to submit your research? Choose BMC and benefit from:

- fast, convenient online submission

- thorough peer review by experienced researchers in your field

- rapid publication on acceptance

- support for research data, including large and complex data types

- gold Open Access which fosters wider collaboration and increased citations

- maximum visibility for your research: over $100 \mathrm{M}$ website views per year

At BMC, research is always in progress.

Learn more biomedcentral.com/submissions 